University of Nebraska - Lincoln

DigitalCommons@University of Nebraska - Lincoln

2004

\title{
Yield Components of Pearl Millet and Grain Sorghum across Environments in the Central Great Plains
}

\author{
Nouri Maman \\ Stephen Mason \\ University of Nebraska-Lincoln, smason1@unl.edu \\ Drew J. Lyon \\ University of Nebraska-Lincoln, drew.lyon@wsu.edu \\ Prabhakar Dhungana
}

Follow this and additional works at: https://digitalcommons.unl.edu/panhandleresext

Part of the Agriculture Commons

Maman, Nouri; Mason, Stephen; Lyon, Drew J.; and Dhungana, Prabhakar, "Yield Components of Pearl Millet and Grain Sorghum across Environments in the Central Great Plains" (2004). Panhandle Research and Extension Center. 3.

https://digitalcommons.unl.edu/panhandleresext/3

This Article is brought to you for free and open access by the Agricultural Research Division of IANR at DigitalCommons@University of Nebraska - Lincoln. It has been accepted for inclusion in Panhandle Research and Extension Center by an authorized administrator of DigitalCommons@University of Nebraska - Lincoln. 


\title{
Yield Components of Pearl Millet and Grain Sorghum across Environments in the Central Great Plains
}

\author{
Nouri Maman, Stephen C. Mason,* Drew J. Lyon, and Prabhakar Dhungana
}

\begin{abstract}
Location, year, and water supply influence the relationship between grain yield and yield components of pearl millet [Pennisetum glaucum (L.) R. Br] and grain sorghum [Sorghum bicolor (L.) Moench]. Field experiments were conducted in 2000 and 2001 on a silt loam soil in semiarid western Nebraska and on a silty clay loam soil in subhumid eastern Nebraska to determine how environment (location, year, water regime) influences number of panicles per square meter, kernel weight, and kernels per panicle in determining grain yield of pearl millet and grain sorghum. Grain yield components were examined by analysis of variance, correlation, and path analysis. Four water regimes were used: (i) no irrigation, (ii) single irrigation at boot stage, (iii) single irrigation at mid-grain fill, and (iv) multiple irrigations. Grain sorghum produced from 109 to $212 \mathrm{~g} \mathrm{~m}^{-2}$ greater yield than pearl millet in all environments in western Nebraska and 52 to $150 \mathrm{~g} \mathrm{~m}^{-2}$ greater yield in eastern Nebraska. Correlation and path analysis direct effects indicated that the number of kernels per panicle $(R$ from $0.36-0.93$; $P$ from $0.21-0.45$ ) and kernel weight $(R$ from $0.46-0.89$; $P$ from $0.46-$ 0.73) were associated with grain yield for both crops at both locations, but in the path analysis, kernel weight was more highly associated with grain yield for grain sorghum ( $P$ from $0.65-0.73$ ) than the number of kernels per panicle ( $P$ from 0.21 and 0.32 ). Plant breeding and production research to increase pearl millet and grain sorghum yield should consider all yield components, but increased emphasis on kernel weight is merited for grain sorghum.
\end{abstract}

Y IELD DIFFERENCES in agronomic crops are associated with kernel number (the product of panicles per square meter and kernels per panicle) and kernel weight. Environmental factors such as temperature and available water influence yield components (Evans and Wardlaw, 1976). Potential for yield compensation occurs early in the plant life cycle through adjustment in the number of panicles per square meter and kernels per panicle. Variation in kernel weight allows for a degree of yield compensation late in the life cycle. Increases in kernels per panicle and in kernel weight may help compensate for low plant populations or limited tillering. As a result of this compensatory power, grain yield in cereals is relatively insensitive to plant population (Anderson, 1986); however, this compensation is less than perfect in grain sorghum (Kiniry, 1988) and pearl millet (Craufurd and Bidinger, 1989).

Eastin and Sullivan (1974) developed simple developmental stage terminology useful for yield and yield com-

Contribution of the Dep. of Agronomy and Horticulture, Univ. of Nebraska, Lincoln, NE 68583-0915. Paper No. 14192 of the Journal Series of the Nebraska Agric. Res. Div. Research Supported in part by the Anna Elliot Fund, Univ. of Nebraska Foundation, and USAID Grant no. DAN 1254-G-0021 through INTSORMIL, the International Sorghum and Millet Collaborative Research Program. Received 30 July 2003. *Corresponding author (smason1@unl.edu).

Published in Crop Sci. 44:2138-2145 (2004).

(c) Crop Science Society of America

677 S. Segoe Rd., Madison, WI 53711 USA ponent analyses for grain sorghum on the basis of growth stage as follows: (i) the vegetative period from planting to panicle initiation (GS1); (ii) the reproductive period (GS2) from panicle initiation to flowering; and (iii) grain filling period (GS3) from flowering to physiological maturity. These three developmental stages were similarly described for pearl millet by Maiti and Bidinger (1981). For grain sorghum and pearl millet, potential kernel number is set during GS2 and kernel weight is determined within genetic limits during GS3 (Eastin et al., 1999; Maiti and Bidinger, 1981). Water or temperature stress during late GS1 and GS2 can reduce kernel number irreversibly and adequate water during grain fill can do little to ameliorate the loss in grain yield except for limited increase in kernel weight. During GS3, grain sorghum grain yield has been found to be less sensitive to water stress than during GS2, and the lower yield reduction was largely due to reduced kernel weight (Eastin et al., 1983). Yield component studies with grain sorghum have shown the number of panicles per square meter to be a yield component associated with yield changes from nonuniform stand reductions (Larson and Vanderlip, 1994), border effects in strip intercropping (Lesoing and Francis, 1999) and $\mathrm{N}$ application (Rajewski et al., 1991); kernels per panicle for weed competition (Limon-Ortega et al., 1998), nonuniform stand establishment (Larson and Vanderlip, 1994), row spacing and plant population (Stickler and Wearden, 1965; M'Khaitir and Vanderlip, 1992), delayed planting (M'Khaitir and Vanderlip, 1992), soil water storage differences (Norwood, 1992), and defoliation (Rajewski et al., 1991); and kernel weight for environmental differences (Heinrich et al., 1985; Saeed et al., 1986; Rajewski et al., 1991), row spacing and plant population (Stickler and Wearden, 1965), and soil water storage differences (Norwood, 1992). Yield component studies with pearl millet have shown the number of panicles per plant to be the yield component most associated with yield changes with plant population, but because of profuse tillering, the number of panicles per square meter may decrease (van Oosterom et al., 2002) or remain nearly constant (Carberry et al., 1985; M'Khaitir and Vanderlip, 1992) with increasing plant population. Panicles per square meter or panicles per plant is the yield component most often associated with grain yield grain yield differences due to preflowering water stress (Mahalakshmi and Bidinger, 1986); kernels per panicle for mid-season water stress (Bidinger et al., 1987), temperature (Ong, 1983), and weed competition (Limon-Ortega et al., 1998); and kernel weight for terminal water stress (Bidinger et al., 1987) and temperature (Ong, 1983).

Since yield components are interrelated, have compensatory effects, and develop sequentially at different growth stages, path coefficient analysis is often used to 
characterize yield component variations at the phenotypic and genotypic levels, and to identify plant breeding and/or crop management research priorities (Board et al., 1999) and expand physiological understanding of crop morphology (García del Moral et al., 2003). Path coefficient analysis provides more information among variables than do simple correlation coefficients since this analysis provides the direct effects of specific yield components on yield, and indirect effects via other yield components (García del Moral et al., 2003).

This research was conducted to determine the effect of environment (year, location, water regime) on the yield components of grain sorghum and pearl millet, with the hope of identifying the yield component(s) of pearl millet and grain sorghum most critical in Central Great Plains production environments. The research focus was on western Nebraska where this experiment was conducted to determine the potential for pearl millet and grain sorghum as crops. The eastern Nebraska location provided a reference point for a region where grain sorghum is widely grown. Our hypotheses were that environment would alter those yield components that are most closely associated with grain yield in pearl millet and grain sorghum, and that (i) under limited water stress, the number of panicles per square meter would be the most important yield contributor for both crops, (ii) since kernel number is set during GS2, irrigation at boot stage would create conditions making kernels per panicle the most important contributor to grain yield for both crops, and (iii) with irrigation at mid-grain fill, kernel weight would be the greatest contributor to yield for both crops.

\section{MATERIALS AND METHODS}

Field experiments were conducted in western and eastern Nebraska in 2000 and 2001. The western Nebraska experiment was conducted at the University of Nebraska High Plains Agricultural Laboratory located $8 \mathrm{~km}$ north of Sidney, NE $\left(+41.2^{\circ},-130.0^{\circ}\right.$, at $1317 \mathrm{~m}$ elevation $)$. Soil at the site is a Keith silt loam (fine-silty, mixed, superactive mesic, Aridic Argiustoll), and its chemical properties are presented in Table 1. Available water capacities for the soil are 0.20 to $0.23 \mathrm{~cm} \mathrm{~cm}^{-1}$ for the 0 - to $25-\mathrm{cm}$ depth, 0.18 to $0.22 \mathrm{~cm} \mathrm{~cm}^{-1}$ for the 25- to $58-\mathrm{cm}$ depth, and $0.20-$ to $0.22-\mathrm{cm} \mathrm{cm}^{-1}$ for the 58- to 152-cm depth (Borchers and Hartung, 1997). Pearl millet and grain sorghum are not widely grown in this region at present but potential exists for production of both crops.

The eastern Nebraska experiment was conducted at the University of Nebraska Agricultural Research and Develop- ment Center near Mead, NE $\left(+41.14^{\circ},-96.29^{\circ} ; 369 \mathrm{~m}\right.$ elevation) and was included in the study to provide a higher yield production environment. Soil at the site is a Sharpsburg silty clay loam (fine, smectitic, mesic, Typic Argiudoll), and its chemical properties are presented in Table 1. Available water holding capacities for the soil are 0.21 to $0.23 \mathrm{~cm} \mathrm{~cm}^{-1}$ for the 0 - to $30-\mathrm{cm}$ depth, and 0.18 to $0.20 \mathrm{~cm} \mathrm{~cm}^{-1}$ for the 30 - to 152-cm depth (Kerl et al., 1982). Soil tests showed adequate nutrient levels at both locations except for N, which was applied at the recommended rate of $112 \mathrm{~kg} \mathrm{ha}^{-1}$ at Mead and zero to $40 \mathrm{~kg} \mathrm{ha}^{-1}$ at Sidney. Mead is located in an important grain sorghum production region.

The treatment structure was a $4 \times 2$ factorial at both locations. Factor one consisted of four water regimes chosen to reflect the range of environments possible at both locations: (i) no irrigation, (ii) single irrigation at boot stage, (iii) single irrigation at mid-grain fill, and (iv) multiple irrigations. Factor two consisted of two crops: a pearl millet hybrid $(68 \mathrm{~A} \times 086 \mathrm{R})$ and an early maturing grain sorghum hybrid (DK 28E). These were the best-adapted hybrids available for the Sidney location on the basis of performance tests. The experimental designs were different at the two locations becaue of a difference in irrigation systems available at the two sites. At Sidney, where the irrigation system was a lateral-move system with drop-nozzle booms, the experiment was conducted as a randomized complete block design with four replications. Plot size was $9.1 \mathrm{~m}$ (12 rows $76 \mathrm{~cm}$ apart) wide and $9.1 \mathrm{~m}$ long with 3-m alleys between plots. At Mead, where a furrow irrigation system was used, the experiment was conducted as a randomized complete block design with a split-plot treatment arrangement and four replications. The whole plot treatments were four water regimes, and the split plot treatment was crop. Plot size was $6.8 \mathrm{~m}$ wide (nine rows $76 \mathrm{~cm}$ apart) and $9.1 \mathrm{~m}$ long.

At Sidney, both pearl millet and grain sorghum were notill planted into wheat stubble on 8 June 2000 and 11 June 2001. At Mead, the experimental area was disked before planting. Pearl millet and grain sorghum were planted on 1 June 2000 and 18 June 2001. At Sidney, final plant stands were $11.2 \pm 0.7$ plants $\mathrm{m}^{-2}$ for pearl millet and $11.3 \pm 0.7$ plants $\mathrm{m}^{-2}$ for grain sorghum in 2000. In 2001 plants stands were $13.5 \pm 1.1$ plants $\mathrm{m}^{-2}$ for pearl millet and $12.7 \pm 1.1$ plants $\mathrm{m}^{-2}$ for grain sorghum. At Mead, plant stands were $17.6 \pm$ 0.2 plants $\mathrm{m}^{-2}$ for grain sorghum and $17.4 \pm 0.3$ plants $\mathrm{m}^{-2}$ for pearl millet in both years. All plant populations were within the recommended range for both crops at these locations.

Weed management involved the use of herbicides, cultivation, and hand hoeing. At Sidney, propazine [6-chloro- $N, N^{\prime}$,-bis (1-methylethyl)-1,3,5-triazine-2,4-diamine] was applied preemergence at $1.12 \mathrm{~kg} \mathrm{ha}^{-1}$. At Mead, atrazine [(6-chloro$N$-ethyl- $N^{\prime}$-(1-methyl)-1,3,5-triazine-2, 4-diamine] was applied pre-emergent at $1.12 \mathrm{~kg} \mathrm{ha}^{-1}$. When pearl millet reached the three-leaf stage, atrazine at $0.6 \mathrm{~kg} \mathrm{ha}{ }^{-1}$ plus $2.2 \mathrm{~kg} \mathrm{ha}^{-1}$ of metolachlor [2-chloro-(2-ethyl-6-methylphenyl)-(2-meth-

Table 1. Growing season monthly average temperatures at Sidney, NE. Source: High Plains Regional Climate Center, University of Nebraska, Lincoln, NE.

\begin{tabular}{|c|c|c|c|c|c|c|c|c|c|}
\hline \multirow[b]{3}{*}{ Month } & \multicolumn{6}{|c|}{ Temperature } & & & \\
\hline & \multicolumn{2}{|c|}{2000} & \multicolumn{2}{|c|}{2001} & \multicolumn{2}{|c|}{ 30-yr average } & \multicolumn{3}{|c|}{ Precipitation } \\
\hline & Low & High & Low & High & Low & High & 2000 & 2001 & 30-yr average \\
\hline & \multicolumn{6}{|c|}{$-{ }^{\circ} \mathbf{C}-$} & \multicolumn{3}{|c|}{$\mathbf{m m}$} \\
\hline May & 7.0 & 22.7 & 6.1 & 19.8 & 5.6 & 21.4 & 45 & 100 & 77 \\
\hline June & 10.7 & 28.9 & 10.5 & 27.5 & 11.2 & 27.4 & 27 & 36 & 73 \\
\hline July & 15.3 & 33.1 & 16.2 & 32.3 & 14.4 & 31.3 & 18 & 92 & 62 \\
\hline August & 14.8 & 33.1 & 13.6 & 31.4 & 12.9 & 29.9 & 12 & 61 & 39 \\
\hline September & 8.2 & 25.9 & 9.4 & 25.7 & 7.2 & 24.6 & 39 & 65 & 34 \\
\hline Total & & & & & & & 141 & 354 & 285 \\
\hline
\end{tabular}




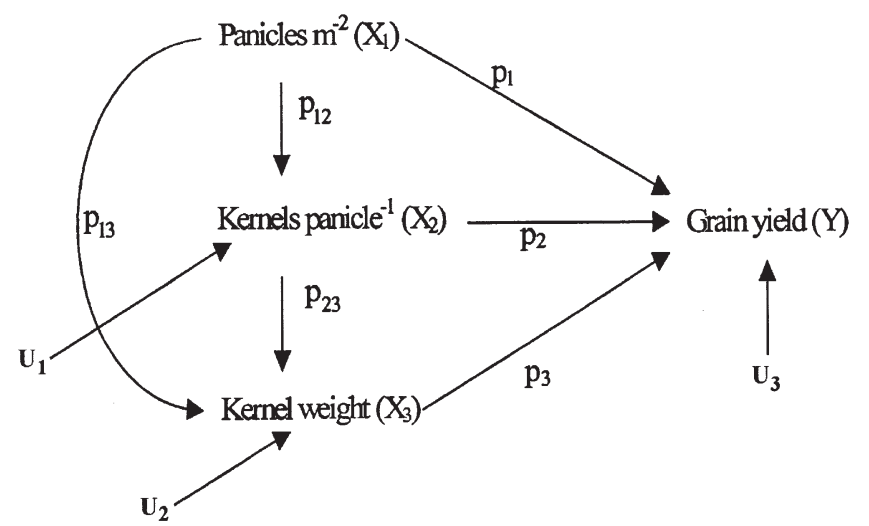

Fig. 1. Path diagram for the three yield component variables $X_{1}, X_{2}$, and $X_{3}$ and grain yield as the response variable (Y), where $Y=$ $P_{1}+P_{2} X_{2}+P_{3} X_{3}+U_{3} ; X_{3}=P_{13} X_{1}+P_{23} X_{2}+U_{2} ; X_{2}=P_{12} X_{1}+U_{1}$.

oxy-1-methylethyl) acetamide] and $0.56 \mathrm{~kg} \mathrm{ha}^{-1}$ of bentazon [3-(1-methylethyl)-(1H)-2, 1,3-benzothiadiazin-4 (3H)-one 2,2dioxide] were applied.

At Sidney, a neutron probe (Campbell Pacific 503 DR, Campbell Pacific, Pacheco, CA) was used to monitor soil water content on a weekly basis. For the multiple irrigation treatment, irrigation water was applied whenever available soil water fell below $70 \%$ of the available soil water holding capacity. Irrigation water was applied to bring the available soil water level to at least $80 \%$ of the available soil water capacity. Supplemental water applications were made in $25-\mathrm{mm}$ increments with a 1-d interval between applications to avoid runoff. Multiple irrigation treatment received 305 and $102 \mathrm{~mm}$ supplemental water application and in 2000 and 2001. Boot stage supplemental irrigation treatment received 127 and $25 \mathrm{~mm}$ in 2000 and 2001. Grain fill irrigation received 127 and $76 \mathrm{~mm}$ supplemental water in 2000 and 2001. At Mead, the decision to irrigate in all irrigation treatments was based on physical observation of crop stress and soil water content using the feel method (USDA, 1998). Furrow irrigation was used, with flow rate being controlled by adjusting the irrigation pump speed and gate openings on the irrigation pipe. Irrigated plots at Mead were brought to field capacity with each irrigation.

Two central rows, $3 \mathrm{~m}$ long, were hand-harvested from each plot to determine grain yield, and yield components. Before harvest, the number of panicles per square meter were counted in the harvest area, then 10-panicle subsamples were randomly harvested before grain yield harvest from these two rows to determine kernels per panicle and kernel weight. These subsamples were threshed, counted, and weighed separately from the rest of the harvest area, and the weights were added back for determination of grain yield. Grain from the 10-panicle subsamples were counted, weighed and corrected for water content to determine number of kernels per panicle and kernel weight. Grain yield and yield components were corrected to $140 \mathrm{~g} \mathrm{~kg}^{-1}$ water content by drying at $60^{\circ} \mathrm{C}$ for at least $48 \mathrm{~h}$.

Analyses of variance for grain yield and each yield component was conducted by the Mixed Models procedure of the SAS package as presented by Littell et al. (1996) and pooled across years since variances were similar on the basis of the $F$ ratio test. Analyses were not combined across locations because of the use of different treatment arrangements, irrigation methods, plant populations, and the widely contrasting climatic conditions. Mean separation was done by PROC Mixed LSMeans P difference. Year, location, hybrid, and water treatments were all considered to be fixed effects.

Pearson correlations among yield and yield components were calculated using replicate values. Direct path coefficients (P) were determined with the CALIS procedure of SAS (SAS Inst., 1994) using the model proposed by Dofing and Knight (1992; Fig. 1). Because of limited number of water regime observations, path analysis was conducted across water regimes only, giving $n=28$ at Sidney and $n=32$ at Mead. Correlation and path analyses data were presented following the method used by García del Moral et al. (2003).

\section{RESULTS AND DISCUSSION}

In 2000 and 2001, high and low temperatures were near long-term averages at Mead and slightly greater than average at Sidney (Tables 1 and 2). Monthly low temperatures during the growing season were lower at Sidney than Mead except for July 2000. Monthly high temperatures were higher at Sidney than Mead in July and August 2000, but similar in 2001. Rainfall was less than $50 \%$ of the long-term seasonal average at Sidney and $25 \%$ less at Mead in 2000. Rainfall was above the long-term average at both locations in 2001. However, Sidney rainfall was $24 \%$ above the long-term average and evenly distributed throughout the growing season, while above-average rainfall was only received in May before planting at Mead.

In the dry 2000 season at Sidney, single irrigation treatments at boot and grain fill stages had rainfall $(141 \mathrm{~mm})+$ irrigation $(127 \mathrm{~mm})$ approximately equal to the average annual seasonal rainfall (Table 1). Multiple irrigations treatments in both years had rainfall $(141 \mathrm{~mm}$ in 2000 and $354 \mathrm{~mm}$ in 2001) + irrigation (305 $\mathrm{mm}$ in 2000 and $102 \mathrm{~mm}$ in 2001) of approximately $450 \mathrm{~mm}$ which was approximately $57 \%$ greater than the average seasonal rainfall. Season rainfall plus irrigation was $40 \%$ greater than the average seasonal rainfall in 2001 for the boot irrigation treatment, and $60 \%$ greater for the

Table 2. Growing season monthly average temperatures, and total precipitation at the Agronomy Farm near Mead, NE. Source: High Plains Regional Climate Center, University of Nebraska, Lincoln, NE.

\begin{tabular}{|c|c|c|c|c|c|c|c|c|c|}
\hline \multirow[b]{3}{*}{ Month } & \multicolumn{6}{|c|}{ Temperature } & & & \\
\hline & \multicolumn{2}{|c|}{2000} & \multicolumn{2}{|c|}{2001} & \multicolumn{2}{|c|}{ 30-yr average } & \multicolumn{3}{|c|}{ Precipitation } \\
\hline & Low & High & Low & High & Low & High & 2000 & 2001 & 30-yr average \\
\hline & & & & 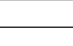 & 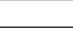 & - & 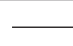 & - & 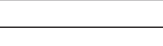 \\
\hline May & 11.2 & 26.3 & 11.5 & 23.4 & 10.6 & 23.4 & 70 & 230 & 105 \\
\hline June & 14.4 & 28.5 & 15.5 & 28.0 & 16.2 & 29.1 & 152 & 40 & 106 \\
\hline July & 14.4 & 29.3 & 19.8 & 31.9 & 19.2 & 31.7 & 88 & 25 & 87 \\
\hline August & 19.0 & 31.1 & 17.1 & 30.9 & 17.7 & 30.1 & 43 & 79 & 92 \\
\hline September & 11.1 & 28.0 & 11.2 & 25.0 & 12.3 & 25.0 & 15 & 67 & 90 \\
\hline Total & & & & & & & 369 & 440 & 480 \\
\hline
\end{tabular}


grain-fill irrigation. At Mead, the furrow irrigation system used did not allow determination of the exact amount of water supplied, but plots were brought to field capacity with each irrigation application.

\section{Yield and Yield Components}

\section{Year $\times$ Crop Interactions}

Grain yields for pearl millet and grain sorghum were lower in the more stressful, shorter growing season environments at Sidney than at Mead and in the more stressful year 2000 than 2001 (Tables 3 and 4). Grain yield was higher for both crops at both locations in 2001 than in 2000 , but the grain yield increase was greater for grain sorghum than pearl millet. In 2000 and 2001, average pearl millet grain yields were 85 and $82 \%$ of sorghum grain yields at Mead, while pearl millet yields were 51 and $76 \%$ of sorghum grain yields at Sidney. These lower pearl millet yields across environments as compared with grain sorghum confirm a recent report (Palé et al., 2003) that pearl millet does not have at present, adequate grain yield potential to replace grain sorghum as a grain crop in the Central Great Plains.

The higher grain yields in 2001 than in 2000 (Tables 3 and 4) were accompanied by an increase in kernel weight, except for pearl millet at Mead. Pearl millet produced more panicles per square meter than grain sorghum in all environments, and grain sorghum kernels were 1.9 to $2.4 \mathrm{mg} \mathrm{kernel}^{-1}$ heavier than pearl millet, which is in agreement with finding of Christensen et al. (1987). Pearl millet produced a similar number of panicles per square meter across years even though final stands were 2.1 plants $\mathrm{m}^{-2}$ lower at Sidney in 2000 than in 2001, and dramatically different climatic conditions occurred in these two years. This is consistent with results of Carberry et al. (1985), M'Khaitir and Vanderlip (1992) and Mahalakshmi and Bidinger (1986). Pearl millet produced more kernels per panicle in 2001 than in 2000 at both locations. In contrast, grain sorghum produced a similar number of kernels per panicle across years, but more panicles per square meter in 2001 than in 2000. Both crops produced lower grain yield and lighter kernel weights at the more stressful, shorter growing season Sidney location than at Mead, except for pearl millet in 2001. Pearl millet produced more panicles per square meter and fewer kernels per panicle at Sidney than at Mead. In contrast, grain sorghum produced a similar number of panicles per square meter and more kernels per panicle at Sidney than at Mead. These data indicate that although grain yield responses to year and location were similar for both crops, the yield component changes differed between crops for years and locations.

Table 3. Pearl millet and grain sorghum grain yield, and yield components, as affected by crop and water regime at Sidney, NE in 2000 and 2001.

\begin{tabular}{|c|c|c|c|c|c|}
\hline & & Grain yield & Number of panicles & Number of kernels & Kernel weight \\
\hline & & $\mathbf{g ~ m}^{-2}$ & $\mathbf{m}^{-2}$ & panicle $^{-1}$ & mg \\
\hline \multicolumn{6}{|c|}{ Year $\times$ crop interaction } \\
\hline Year & & & & & \\
\hline 2000 & pearl millet & 210a & 25.8a & $1300 a$ & $7 \mathbf{a}$ \\
\hline & grain sorghum & 414b & 13.9b & $1940 b$ & $\mathbf{1 7 b}$ \\
\hline 2001 & pearl millet & $385 a$ & 24.6a & $2040 a$ & $11 a$ \\
\hline & grain sorghum & $\mathbf{5 0 4 b}$ & $16.9 b$ & $1950 a$ & $21 b$ \\
\hline \multicolumn{6}{|c|}{ Year $\times$ water regime interaction } \\
\hline Year & & & & & \\
\hline \multirow[t]{4}{*}{2000} & no irrigation & $144 a$ & 13.1a & $1204 a$ & $\mathbf{1 0 a}$ \\
\hline & boot irrigation & $270 b$ & $22.0 \mathrm{c}$ & $1580 b$ & $11 b$ \\
\hline & grain fill irrigation & $335 \mathrm{c}$ & $18.5 b$ & $1721 b$ & $13 \mathrm{c}$ \\
\hline & multiple irrigations & 490d & 25.9d & $1944 c$ & 14d \\
\hline \multirow[t]{5}{*}{2001} & no irrigation & $356 a$ & 21.1a & $1947 a$ & 15a \\
\hline & boot irrigation & $406 a$ & $20.7 \mathbf{a}$ & $1985 a$ & $16 \mathbf{a}$ \\
\hline & grain fill irrigation & $463 b$ & 19.6a & $1944 a$ & $16 b$ \\
\hline & multiple irrigations & $553 c$ & $21.8 a$ & $2107 a$ & $\mathbf{1 7 b}$ \\
\hline & \multicolumn{5}{|c|}{ Crop $\times$ water regime interaction } \\
\hline \multicolumn{6}{|l|}{ Pearl millet } \\
\hline & no irrigation & $197 \mathbf{a}$ & 20.7a & $1370 a$ & $8 \mathbf{a}$ \\
\hline & boot irrigation & 233a & 27.3c & $1630 b$ & $\mathbf{8 a}$ \\
\hline & mid-grain fill irrigation & 329b & 24.0b & $1730 b$ & 10b \\
\hline & multiple irrigations & 431c & $28.9 c$ & $1970 \mathrm{c}$ & $10 b$ \\
\hline \multicolumn{6}{|l|}{ Grain sorghum } \\
\hline & no irrigation & $306 a$ & $13.4 a$ & $1790 a$ & 16a \\
\hline & boot irrigation & $445 b$ & $15.4 a$ & $1950 \mathrm{ab}$ & $18 b$ \\
\hline & mid-grain fill irrigation & 472b & 14.1a & 1940 ab & $19 \mathrm{c}$ \\
\hline & multiple irrigations & $615 c$ & $18.8 b$ & $2090 b$ & 21d \\
\hline \multicolumn{6}{|c|}{$F$ test and contrast probabilities $(\operatorname{Pr}>F)$} \\
\hline Year $(Y)$ & & $<0.01$ & 0.13 & $<\mathbf{0 . 0 1}$ & $<0.01$ \\
\hline Water regime (WR) & & $<\mathbf{0 . 0 1}$ & $\mathbf{0 . 0 8}$ & $<\mathbf{0 . 0 1}$ & $<\mathbf{0 . 0 1}$ \\
\hline Crop (C) & & $<\mathbf{0 . 0 1}$ & $<\mathbf{0 . 0 1}$ & $<\mathbf{0 . 0 1}$ & $<\mathbf{0 . 0 1}$ \\
\hline $\mathbf{Y} \times \mathbf{W R}$ & & $<\mathbf{0 . 0 1}$ & $<\mathbf{0 . 0 1}$ & $<\mathbf{0 . 0 1}$ & $<\mathbf{0 . 0 1}$ \\
\hline $\mathbf{Y} \times \mathbf{C}$ & & $<\mathbf{0 . 0 1}$ & $<\mathbf{0 . 0 1}$ & 0.01 & $\mathbf{0 . 3 7}$ \\
\hline $\mathbf{W R} \times \mathbf{C}$ & & 0.06 & 0.08 & 0.20 & $<\mathbf{0 . 0 1}$ \\
\hline $\mathbf{Y} \times \mathbf{W R} \times \mathbf{C}$ & & 0.23 & $<\mathbf{0 . 0 1}$ & 0.16 & 0.17 \\
\hline MSE (year) & & 9492 & 19.3 & $35789 \dagger$ & 2.01 \\
\hline MSE (residual) & & 2629 & 5.2 & 35789 & 0.58 \\
\hline
\end{tabular}

$\dagger$ MSE for given source was smaller, therefore used for $\boldsymbol{F}$ test. Same letters indicate no significant differences within year or crop. 
Table 4. Pearl millet and grain sorghum grain yield, and yield components, as affected by water regime at Mead, NE, in 2000 and 2001.

\begin{tabular}{|c|c|c|c|c|c|}
\hline & & Grain yield & Number of panicles & Number of kernels & Kernel weight \\
\hline & & $\mathbf{g ~ m}^{-2}$ & $\mathbf{m}^{-2}$ & panicle $^{-1}$ & mg \\
\hline \multicolumn{6}{|c|}{ Year $\times$ crop interaction } \\
\hline Year & & & & & \\
\hline 2000 & pearl millet & $484 a$ & 19.7a & $2550 a$ & 11a \\
\hline & grain sorghum & $\mathbf{5 7 2 b}$ & 17.6a & $1400 b$ & 21b \\
\hline 2001 & pearl millet & $529 a$ & 19.5a & $2780 a$ & 11a \\
\hline & grain sorghum & $645 b$ & $15.3 b$ & $1440 b$ & $26 b$ \\
\hline \multicolumn{6}{|c|}{ Crop $\times$ water regime interaction } \\
\hline \multicolumn{6}{|l|}{ Pearl millet } \\
\hline & no irrigation & 478a & 19.8a & $2560 a$ & $\mathbf{1 0 a}$ \\
\hline & boot irrigation & 494ab & 19.1a & $2660 \mathrm{ab}$ & $11 a$ \\
\hline & mid-grain fill irrigation & $531 b$ & 18.8a & $2640 a$ & $11 a$ \\
\hline & multiple irrigations & $\mathbf{5 2 4 b}$ & 21.2a & $2800 b$ & $11 a$ \\
\hline \multicolumn{6}{|l|}{ Grain sorghum } \\
\hline & no irrigation & $530 a$ & $15.6 a$ & $1330 a$ & 21a \\
\hline & boot irrigation & $600 b$ & 19.1b & $1310 a$ & 23b \\
\hline & mid-grain fill irrigation & $630 b$ & 16.5a & $1540 b$ & $24 c$ \\
\hline & multiple irrigations & $674 c$ & $19.3 b$ & $1510 b$ & $24 c$ \\
\hline \multicolumn{6}{|c|}{$F$ test and contrast probabilities $(\operatorname{Pr}>F)$} \\
\hline Year $(\mathbf{Y})$ & & $<0.01$ & $<<0.01$ & $<\mathbf{0 . 0 1}$ & $<\mathbf{0 . 0 1}$ \\
\hline Water regime (WR) & & $<\mathbf{0 . 0 1}$ & 0.08 & $<\mathbf{0 . 0 1}$ & $<\mathbf{0 . 0 1}$ \\
\hline $\mathbf{Y} \times \mathbf{W R}$ & & 0.08 & 0.54 & 0.36 & 0.63 \\
\hline Crop (C) & & $<\mathbf{0 . 0 1}$ & $<\mathbf{0 . 0 1}$ & $<\mathbf{0 . 0 1}$ & $<\mathbf{0 . 0 1}$ \\
\hline $\mathbf{Y} \times \mathbf{C}$ & & 0.14 & $<\mathbf{0 . 0 1}$ & 0.01 & $<\mathbf{0 . 0 1}$ \\
\hline $\mathbf{W R} \times \mathbf{C}$ & & 0.01 & 0.08 & 0.13 & 0.05 \\
\hline $\mathbf{Y} \times \mathbf{W R} \times \mathbf{C}$ & & 0.58 & 0.10 & 0.54 & 0.52 \\
\hline MSE (year) & & 2821 & $8.0 \dagger$ & $26608 \dagger$ & 1.80 \\
\hline MSE (water regime) & & $1498 \dagger$ & 8.0 & $26608 \dagger$ & 1.79 \\
\hline MSE (residual) & & 1498 & 4.8 & 26608 & 1.72 \\
\hline
\end{tabular}

$\uparrow$ MSE for given source was smaller, therefore used for $\boldsymbol{F}$ test. Same letters indicate no significant differences within year or crop.

\section{Correlations}

Pearl millet and sorghum grain yields were correlated with kernels per panicle and kernel weight for both crops at both locations and also with panicles per square meter for grain sorghum at Sidney (Table 5). These results for grain sorghum are generally consistent with those of Rajewski et al. (1991), although they found kernel weight to have a higher correlation with yield than kernels per square meter. Saeed et al. (1986) found that the number of kernels per panicle was the major contributing factor to grain sorghum yield across dryland production environments, but the relative importance of kernel weight increased with increasing night temperature. Heinrich et al. (1985) concluded that grain sorghum kernel weight contributed to yield stability in low-yield environments and should be an objective of a breeding program for low input agriculture, while in this study, the correlation of kernel weight with grain yield was higher for the high yield environment at Mead.
The pearl millet kernels per panicle association with grain yield is similar to those found by van Oosterom et al. (2002), while the kernel weight association with grain yield was similar to that reported by Bidinger et al. (1987) but contrasted with results of Carberry et al. (1985) who found kernel weight to be relatively constant.

The number of grain sorghum panicles per square meter was correlated with kernel weight at both locations but were negatively correlated in the less stressful environment at Mead as previously found by Kiniry (1988) and were positively correlated in the more stressful Sidney environment (Table 5). Also, the number of grain sorghum kernels per panicle was positively correlated with kernel weight at Sidney but not at Mead. No relationship between the number of pearl millet panicles per square meter was found with either the number of kernels per panicles or kernel weight at both locations. This contrasts with Ong and Monteith (1985) who found that reductions in pearl millet kernels per panicles due

Table 5. Pearson correlation coefficients among yield and yield components of pearl millet and grain sorghum grown in Sidney and Mead, NE, in 2000 and 2001.

\begin{tabular}{|c|c|c|c|c|c|c|}
\hline & \multicolumn{3}{|c|}{ Pearl millet } & \multicolumn{3}{|c|}{ Grain sorghum } \\
\hline & Grain yield & Panicles $\mathbf{m}^{-2}$ & Kernels panicle $^{-1}$ & Grain yield & Panicles $\mathbf{m}^{-2}$ & Kernels panicle $^{-1}$ \\
\hline \multicolumn{7}{|l|}{ Sidney } \\
\hline Panicles $\mathbf{m}^{-2}$ & 0.34 & & & $0.80 * * * *$ & & \\
\hline Kernels panicle $^{-1}$ & $0.93 * * * *$ & 0.32 & & $0.86^{* * *}$ & $0.47 * *$ & \\
\hline Kernel weight & $0.89 * * *$ & 0.08 & $0.92 * * *$ & $0.51 * *$ & $0.82 * * * *$ & 0.33 \\
\hline \multicolumn{7}{|l|}{ Mead } \\
\hline Panicles m ${ }^{-2}$ & -0.19 & & & $-\mathbf{0 . 0 3}$ & & \\
\hline Kernels panicle $^{-1}$ & $0.36 *$ & 0.19 & & $0.36^{*}$ & -0.20 & \\
\hline Kernel weight & $0.46 * *$ & 0.15 & 0.12 & $0.64 * * *$ & $-0.41^{*}$ & 0.15 \\
\hline
\end{tabular}

* Indicates significance at $\boldsymbol{P} \leq \mathbf{0 . 0 5}$.

*** Indicates significance at $\boldsymbol{P} \leq \mathbf{0 . 0 1}$.

$* * *$ Indicates significance at $\boldsymbol{P} \leq \mathbf{0 . 0 0 1}$. 
Table 6. Path coefficient (P) analysis of pearl millet grain yield and yield components in Sidney and Mead, NE, in 2000 and 2001.

\begin{tabular}{|c|c|c|c|c|}
\hline \multirow[b]{2}{*}{ Pathway } & \multicolumn{2}{|c|}{ Sidney } & \multicolumn{2}{|c|}{ Mead } \\
\hline & Pearl millet & Grain sorghum & Pearl millet & Grain sorghum \\
\hline \multirow{2}{*}{\multicolumn{5}{|c|}{ Panicle $\mathrm{m}^{-2}$ vs. grain yield }} \\
\hline & & & & \\
\hline Direct effect, $\stackrel{\mathbf{P}}{21}_{2}$ & 0.16 & 0.17 & $-0.33^{*}$ & $0.34 *$ \\
\hline Indirect effect via kernels panicle ${ }^{-1}, \mathbf{P}_{24} \mathbf{P}_{41}$ & 0.14 & 0.10 & 0.07 & -0.06 \\
\hline Indirect effect via kernel weight, $\mathbf{P}_{24} \mathbf{P}_{43} \mathbf{P}_{31}+\mathbf{P}_{23} \mathbf{P}_{31}$ & 0.04 & $0.53 * *$ & 0.07 & $-0.30 * *$ \\
\hline \multicolumn{5}{|l|}{$\begin{array}{l}\text { Kernel panicle }^{-1} \text { vs. grain yield } \\
\text { S }\end{array}$} \\
\hline Direct effect, $P_{41}$ & $0.45^{*}$ & $0.21 *$ & $0.37^{* *}$ & $0.32 * *$ \\
\hline Indirect effect via kernel weight, $\mathbf{P}_{43} \mathbf{P}_{31}$ & $0.46^{*}$ & -0.05 & 0.05 & 0.05 \\
\hline \multicolumn{5}{|l|}{ Kernel weight vs. grain yield } \\
\hline Direct effect, $P_{31}$ & $0.46^{*}$ & $0.65^{*}$ & $0.47^{*}$ & $0.73 * *$ \\
\hline Residual, $\mathbf{U}_{3}$ & 0.34 & 0.45 & 0.77 & 0.65 \\
\hline
\end{tabular}

* Indicates significance at $\boldsymbol{P} \leq \mathbf{0 . 0 5}$.

** Indicates significance at $P \leq \mathbf{0 . 0 1}$.

to temperature and amount of radiation increased kernel weight.

\section{Path Analysis}

Model multiple correlations across water regimes indicated that the model used accounted for most of the grain yield variation at Sidney but only approximately $50 \%$ of the variation at Mead (Table 6). Direct effects were found for kernels per panicle and kernel weight to grain yield for both crops, but kernel weight direct effects were much larger for grain sorghum than for pearl millet. A direct effect for panicles per square meter to grain yield was found at Mead for both crops but was negative for pearl millet and positive for grain sorghum. This suggests that pearl millet, which prolifically tillers (Egharevba, 1977; Mahalakshmi and Bidinger, 1986), had an excessive number of tillers that produced panicles in this low stress environment and reduced yield, while sorghum grain yield would have benefited from a greater number of tillers producing panicles. Egharevba (1977) found that reducing pearl millet productive tillers per plant from 10 to 3 or 5 increased grain yield by 15 to $30 \%$. Limited yield compensation was found in this study, as indicated by the small number of indirect effects present. However, grain sorghum indirect effects were found for number of panicles per square meter via kernel weight for sorghum grain yield, which was positive at Sidney and negative at Mead. For pearl millet, indirect effects for grain yield were found only for kernels per panicle via kernel weight at Sidney, similar to results of Ong and Monteith (1985).

Grain yield and yield component response data to location and year differences, correlation of grain yield and yield components, and path analysis indicate a similar grain yield response of both crops to different stress conditions although grain sorghum responded better to improved growing conditions than was true for pearl millet. It is clear that yield component panicles per square meter and kernels per panicle responses to location and year were generally reversed for both crops. More panicles per square meter for grain sorghum and kernels per panicle for pearl millet were found in 2001 than in 2000, while more kernels per panicle were found for grain sorghum and more panicles per square meter for pearl millet at Sidney as compared with Mead. In contrast, the response of kernel weight was generally more consistent with heavier kernels in 2001 than in 2000 and at Mead than at Sidney. Correlations and path analysis across years and locations indicated that kernel per panicle and kernel weight were consistently associated positively with grain yield, while panicles per square meter was positively associated with grain yield only for grain sorghum at Mead. Path analysis indicated that kernel weight was particularly important for grain sorghum with $\mathrm{P}$ for direct effects on grain yield ranging from 0.39 to 0.48 more than other yield components.

\section{Crop $\times$ Water Regime Interactions}

Pearl millet grain yield was not increased by a single irrigation at the boot stage at either location (Tables 3 and 4), while a 67 and $119 \%$ increase in response to single irrigation at mid-grain fill, and multiple irrigations treatments was found at Sidney. At Mead, a single irrigation at mid-grain fill and multiple irrigations increased grain yield approximately $10 \%$. Single irrigations at the boot or mid-grain-fill stages increased grain sorghum yields approximately $50 \%$ at Sidney and $15 \%$ at Mead, while multiple irrigations increased grain yield by $100 \%$ at Sidney and $27 \%$ at Mead. Grain yield responses of both crops to multiple irrigations was similar at Sidney, while grain sorghum had a greater grain yield increase at Mead. Sorghum grain yield responded similarly to single irrigation at either the boot or mid-grain fill stages, while pearl millet grain yield responded only to the midgrain fill irrigation.

Pearl millet grain yield increase to multiple irrigations at Sidney was accompanied by increases in all yield components although the kernel weight increase was less than for other yield components, but at Mead, it was accompanied only with an increase in the number of kernels panicles ${ }^{-1}$ (Tables 3 and 4 ). In contrast, sorghum grain yield increase to multiple irrigations at both locations was accompanied by increases in all yield components, with the increase in number of kernels per panicle being less than other yield components at Sidney.

Single irrigations had little effect on pearl millet yield components at Mead (Table 4). In contrast at Sidney, a single irrigation at the boot increased the number of panicles per square meter and kernels panicle, and single irrigation at mid-grain fill increased all yield components (Table 4). For grain sorghum, a single irrigation at boot increased the number of grain sorghum panicles per 
square meter and kernel weight, while mid-grain fill irrigation increased kernel weight at both locations (Tables 3 and 4), and the number of kernels per panicle at Mead. Delayed timing of irrigation generally had a greater effect on kernel weight and less effect on the number of panicles per square meter as expected (Eastin and Sullivan, 1974; Maiti and Bidinger, 1981; Norwood, 1992).

\section{Year $\times$ Water Regime Interactions}

Because of the large differences in the Sidney seasonal precipitation in 2000 and 2001 (Tables 1 and 2), grain yield response to irrigation treatments was much greater in 2000 than in 2001. The increase in average grain yield of the two crops in 2001 was accompanied by changes in kernel weight, while in 2000 all yield components increased. A single irrigation at boot and multiple irrigations increased panicles per square meter more than other yield components, while a single irrigation at the mid-grain fill stage increased all yield components similarly.

\section{CONCLUSIONS}

These results show that grain sorghum has higher yield potential than pearl millet across the diverse environments studied. Sorghum grain yield increased more in response to irrigation than did pearl millet, but pearl millet was more sensitive to environmental differences due to year and location. Grain sorghum number of panicles per square meter and kernel weight responded to irrigation more than pearl millet, while the response of number of kernels per square meter response for both crops were similar. Correlations of grain yield with yield components indicated that the number of kernel per panicle and kernel weight were associated with grain yield, but path correlation direct effects indicated that this association for grain sorghum was greater for kernel weight. Since the grain sorghum and pearl millet hybrids use in this study were the best available for western Nebraska, it is concluded that plant breeding and production research to increase pearl millet and grain sorghum yield in the Central Great Plains should emphasize all yield components, but kernel weight merits increased attention in grain sorghum.

\section{ACKNOWLEDGMENTS}

We appreciate research technical assistance provided by Tom Galusha for the experiment conducted at Mead, and by Rob Higgins for the experiment at Sidney. We acknowledge the valuable assistance of Dr. Kent Eskridge, Department of Statistics, University of Nebraska, Lincoln, NE, with the data analysis used in this paper, and to Drs. Max Clegg and Charles Francis for critical review of the manuscript.

\section{REFERENCES}

Anderson, W.K. 1986. Some relationships between plant population, yield components and grain yield of wheat in a Mediterranean environment. Aust. J. Agric. Res. 37:219-233.

Bidinger, F.R., V. Mahalakshmi, and G.D.P. Rao. 1987. Assessment of drought resistance in pearl millet [Pennisetum americanum (L.) Leeke]. I. Factors affecting yield under stress. Aust. J. Agric. Res. 38:37-48.
Board, J.E., M.S. Kang, and B.G. Harville. 1999. Path analyses of the yield formation for late-planted soybean. Agron. J. 91:128-135.

Borchers, G.A., and S. Hartung. 1997. Soil survey of Cheyenne County. U.S. Gov. Print. Office, Washington, DC.

Carberry, P.S., L.C. Campbell, and F.R. Bidinger. 1985. The growth and development of pearl millet as affected by plant population. Field Crops Res. 11:193-205.

Christensen, N.B., R.L. Vanderlip, and G.A. Milliken. 1987. Response of pearl millet to grain sorghum environments. Field Crop Res. 16:337-348.

Craufurd, P.Q., and F.R. Bidinger. 1989. Potential and realized yield in pearl millet (Pennisetum americanum) as influenced by plant population density and life cycle duration. Field Crops Res. 22: 211-225.

Dofing, S.M., and C.W. Knight. 1992. Alternate model for path analysis of small-grain yield. Crop Sci. 32:487-489.

Eastin, J.D., and C.Y. Sullivan. 1974. Yield consideration in selected cereals. p. 871-877. In R.L. Bielski et al. (ed.) Mechanisms of regulation of plant growth. Bull. 12. Royal Soc. of New Zealand, Wellington, New Zealand.

Eastin, J.D., R.M. Castleberry, T.J. Gerik, J.H. Hulquist, V. Mahalakshmi, V.B. Ounguela, and J.R. Rice. 1983. Physiological aspects of high temperature and water stress. p. 91-112. In C.D. Raper, Jr., and P.J. Kramer (ed.) Crop reaction to water and temperature stresses in humid, temperate climates. Westview Press, Boulder, $\mathrm{CO}$.

Eastin, J.D., C.L. Petersen, F. Zavala-Garcia, A. Dhopte, P.K. Verma, V.B. Ounguela, M.W. Wit, V. Gonzalez Hernandez, M. Livera Munoz, T.J. Gerik, G.I. Gandoul, M.R.A. Hovney, and L. Mendoza Onofre. 1999. Potential heterosis associated with developmental and metabolic processes in sorghum and maize, p. 205-229. In J.G. Coors and S. Pandey (ed.) The genetics and exploitation of heterosis in crops. ASA, CSSA, and SSSA, Madison, WI.

Egharevba, P.N. 1977. Tiller number and millet grain productivity. Cereal Res. Commun. 5:235-247.

Evans, L.T., and I.F. Wardlaw. 1976. Aspects of the comparative physiology of grain yield in cereals. Adv. Agron. 28:301-359.

Garrity, P.D., C.Y. Sullivan, and D.G. Watts. 1983. Moisture deficits and grain sorghum performance: Drought stress conditioning. Agron. J. 75:997-1004.

García del Moral, L.F., Y. Rharrabti, D. Villegas, and C. Royo. 2003. Evaluation of grain yield and its components in durum wheat under Mediterranean conditions: An ontogenic approach. Agron. J. 95: 266-274.

Heinrich, G.M., C.A. Francis, J.D. Eastin, and M. Saeed. 1985. Mechanisms of yield stability in sorghum. Crop Sci. 25:1109-1113.

Kerl, D.E., M. Babcock, and G. Halstead. 1982. Soil survey of Butler County, Nebraska. U.S. Gov. Print. Office, Washington, DC.

Kiniry, J.R. 1988. Kernel weight increase in response to decreased kernel number in sorghum. Agron. J. 80:221-226.

Larson, E.J., and R.L. Vanderlip. 1994. Grain sorghum yield response to nonuniform stand reductions. Agron. J. 86:475-477.

Lesoing, G.W. and C.A. Francis. 1999. Strip intercropping effects on yield and yield components of corn, grain sorghum, and soybean. Agron. J. 91:807-813.

Limon-Ortega, A., S.C. Mason, and A.R. Martin. 1998. Production practices improve grain sorghum and pearl millet competitiveness with weeds. Agron. J. 90:227-232.

Littell, R.C., G.A. Milliken, W.W. Stroup, and R.D. Wolfinger. 1996. SAS system for mixed models. SAS Institute, Cary, NC.

Maiti, R.K., and F.R. Bidinger. 1981. Growth and development of pearl millet plant. ICRISAT Res. Bull. 6. Hyderabad, India.

Mahalakshmi, V., and F.R. Bidinger. 1986. Water deficit during panicle development in pearl millet: Yield compensation by tillers. J. Agric. Sci. (Cambridge) 1986:113-119.

M'Khaitir, Y.O., and R.L. Vanderlip. 1992. Grain sorghum and pearl millet response to date and rate of planting. Agron. J. 84:579-582.

Norwood, C.A. 1992. Tillage and cropping system effects on winter wheat and grain sorghum. J. Prod. Agric. 5:120-126.

Ong, C.K. 1983. Response to temperature in a stand of pearl millet (Pennisetum typhoides): Final number of spikelets and grains. J. Exp. Bot. 34:337-338.

Ong, C.K., and J.L. Monteith. 1985. Response of pearl millet to light and temperature. Field Crops Res. 11:141-160. 
Palé, S., S.C. Mason, and T.D. Galusha. 2003. Planting time for earlyseason pearl millet and grain sorghum in Nebraska. Agron. J. 91:1047-1053.

Rajewski, J., C.A. Francis, and J.D. Eastin. 1991. Differential responses to defoliation of grain sorghum yield components and yield related traits. Crop Sci. 31:561-567.

Saeed, M., C.A. Francis, and M.D. Clegg. 1986. Yield component analysis in grain sorghum. Crop Sci. 26:346-351.

SAS Institute. 1994. SAS/STAT user's guide Version 6, fourth ed. SAS Inst., Cary, NC.
Stickler, F.C., and S. Wearden. 1965. Yield and yield components of grain sorghum as influenced by row width and stand density. Agron. J. 57:564-567.

United States Department of Agriculture. (USDA-NRCS). 1998. Estimating soil moisture by feel and appearance. Program Aid Number 1619. Washington, DC.

van Oosterom, E.J., G.J. O'Leary, P.S. Carberry, and P.Q. Craufurd. 2002. Simulating growth, development, and yield of tillering pearl millet. III. Biomass accumulation and partitioning. Field Crops Res. 79:85-106. 